\title{
Use of the Zebra Mussel Dreissena polymorpha (Mollusca, Bivalvia) as a Bioindicator of Microplastics Pollution in Freshwater Ecosystems: A Case Study from Lake Iseo (North Italy)
}

\author{
Paolo Pastorino ${ }^{1, *(\mathbb{D})}$, Marino Prearo ${ }^{1}\left(\mathbb{D}\right.$, Serena Anselmi ${ }^{2}$, Vasco Menconi ${ }^{1} \mathbb{D}^{\mathbb{D}}$, Marco Bertoli $^{3}$, \\ Alessandro Dondo ${ }^{1}$, Elisabetta Pizzul ${ }^{3}$ (D) and Monia Renzi ${ }^{3}$ \\ 1 The Veterinary Medical Research Institute for Piemonte, Liguria and Valle d'Aosta, via Bologna 148, \\ 10154 Torino, Italy; marino.prearo@izsto.it (M.P.); vasco.menconi@izsto.it (V.M.); \\ alessandro.dondo@izsto.it (A.D.) \\ 2 Bioscience Research Center, via Aurelia Vecchia 32, 58015 Orbetello, Italy; serena.anselmi@bsrc.it \\ 3 Department of Life Sciences, University of Trieste, via L. Giorgieri 10, 34127 Trieste, Italy; \\ marco.ber3@gmail.com (M.B.); pizzul@units.it (E.P.); mrenzi@units.it (M.R.) \\ * Correspondence: paolo.pastorino@izsto.it; Tel.: +39-0112696251
}

\section{check for} updates

Citation: Pastorino, P.; Prearo, M.; Anselmi, S.; Menconi, V.; Bertoli, M.; Dondo, A.; Pizzul, E.; Renzi, M. Use of the Zebra Mussel Dreissena polymorpha (Mollusca, Bivalvia) as a Bioindicator of Microplastics Pollution in Freshwater Ecosystems: A Case Study from Lake Iseo (North Italy). Water 2021, 13, 434. https://doi.org/10.3390/w13040434

Academic Editor: Hrissi

K. Karapanagioti

Received: 19 January 2021

Accepted: 4 February 2021

Published: 7 February 202

Publisher's Note: MDPI stays neutral with regard to jurisdictional claims in published maps and institutional affiliations.

Copyright: (c) 2021 by the authors. Licensee MDPI, Basel, Switzerland. This article is an open access article distributed under the terms and conditions of the Creative Commons Attribution (CC BY) license (https:/ / creativecommons.org/licenses/by/ $4.0 /)$

\begin{abstract}
The monitoring of microplastics pollution in freshwater environments trails behind its practice in marine ecosystems. We evaluated the use of the invasive zebra mussel (Dreissena polymorpha) as a potential bioindicator of microplastic litter in freshwater lakes. Samples were collected from three sites (Lovere, Costa Volpino, Castro) at the northern end of Lake Iseo (one of the major subalpine lakes in north Italy) and compared for water physicochemical parameters, biometrical features of zebra mussels, and microplastics items/specimens (color, shape, size, and chemical composition). We hypothesized that since a wastewater treatment plant (WWTP) on the Oglio River discharges into this area of the lake, the microplastics in D. polymorpha could be measured and compared in samples from the three sites at different distances from the WWTP. There was no difference in the physicochemical water parameters and biometric features between the samples from the three sites, whereas there was a significant difference in items/specimen between the sites in decreasing order (mean \pm standard deviation): Costa Volpino $(0.23 \pm 0.43)>$ Lovere $(0.07 \pm 0.25)>$ Castro $(0.03 \pm 0.18)$. The chi-square test showed a significant difference in shape, color, and chemical composition frequency in the samples from the three sites. The chemical composition of the microplastics was polyethylene terephthalate $(45 \%)$, nylon $(20 \%)$, polypropylene $(20 \%)$, polyamide resin $(10 \%)$, and polyvinyl chloride $(5 \%)$. Our data show that the amount of microplastics the zebra mussel accumulated was greater the closer the sampling site to the WWTP. Our findings suggest that the zebra mussel may provide a useful tool to monitor microplastics pollution in lakes.
\end{abstract}

Keywords: environmental monitoring; freshwater ecosystems; polyethylene terephthalate; nylon; wastewater treatment plant

\section{Introduction}

Environment microplastics pollution is ubiquitous in water, soil, and organisms [1]. Microplastics $(<5 \mathrm{~mm}$ ) can be of primary origin when derived from intentionally produced synthetic materials, such as raw materials for industry or abrasive components in the chemical or cosmetics industry [2]. Differently, microplastics of secondary origin derive from plastics of larger dimension (macroplastics) dispersed in the environment and their subsequent fragmentation by atmospheric agents, mechanical erosion, UV radiation, or biological degradation [3].

Environmental plastics pollution of marine ecosystems has been documented since the 1970s [4]. For many years, attention was largely focused on the possible physical effects 
of macroplastics ( $>5 \mathrm{~mm}$ ), for example, obstruction of the respiratory or the digestive tract of aquatic fauna [5], while research into the possible environmental effects of microplastics is fairly recent by comparison [6]. Surprisingly, even in countries with advanced environmental protection technologies, microplastics concentrations were found to be similar for freshwater and marine environments [7]. Monitoring the effects of microplastics pollution differs from macroplastics because of accumulation phenomena by which they can be more easily transmitted through the trophic chain, both directly and indirectly [8]. Other negative effects may depend on numerous variables, such as chemical composition and particle size, characteristics that become relevant for other undesirable properties such as the absorption potential of other pollutants (i.e., persistent organic contaminants) [9].

Assessment of contaminants in aquatic ecosystems can be carried out with the use of bioindicator organisms in which biological and biochemical parameters are evaluated over time (biomonitoring) [10]. Sessile species are particularly useful for environmental monitoring [11]. For example, marine bivalve mollusks are sensitive bioindicators of aquatic ecosystem pollution [12]. In addition, freshwater bivalves can be used in biomonitoring: They are adequate in size, mostly sessile, long-lived, widely distributed, and available in large quantities [13]. Owing to their ability to accumulate measurable quantities of pollutants, bivalve mollusks are often chosen as environmental signalers (indicator or sentinel organisms) [14]. Among the bivalves, the invasive zebra mussel (Dreissena polymorpha), also present in subalpine lakes in Italy, can be considered as a freshwater biological model to assess the effect of microplastics [15].

It has always aroused interest among scientists as it maintains neotenic features (byssus and planktonic larval stage) that ensure its ability to easily penetrate aquatic ecosystems and form colonies that infest water pumps, ducts, canal walls, and bottoms [16]. It can also alter the ecology of an aquatic system by rapidly establishing large populations that, due to the increased filtration, can alter the flow of energy through the food chain [17]. This stationary filter feeder can concentrate contaminants even if present at low concentration in an environment [18]. As a filter feeder, it pumps large volumes of water, concentrating many xenobiotics in its tissues, microplastics included $[15,19]$. These substances can then be propagated and amplified through the food chain [20].

In Italy, Dreissena polymorpha was introduced in Lake Garda in the early 1970s probably by adult specimens attached to the hull of a boat from central Europe [21]. The species is also widely found in nearby Lake Iseo, where it has been reported since 1990, though it very likely arrived a decade earlier [22]. Lake Iseo is of glacial origin and is fed by the Oglio River, which enters the lake at the town of Costa Volpino (northern end of the lake). Located in the area is a wastewater treatment plant (WWTP) that discharges the treated wastewater (industrial and municipal) into the lake, resulting in chronic sewage and microplastics pollution [23]. Our hypothesis was that since the water from the WWTP is discharged into the northern end of the lake, the microplastics in D. polymorpha could be measured. In this study, we measured and compared the microplastics levels in $D$. polymorpha sampled from sites at different distances from the WWTP to determine whether it can be used as a bioindicator of microplastics pollution in a lake.

\section{Materials and Methods}

\subsection{Study Area}

Lake Iseo stretches in a pre-Alpine furrow between the geographical provinces of Bergamo and Brescia. Furthermore, known by the name of Sebino, Lake Iseo $\left(60.69 \mathrm{~km}^{2}\right.$ in area, maximum depth $251 \mathrm{~m}$, average depth $123 \mathrm{~m}$ ) is a holo-oligomictic lake with a theoretical turnover time of 4.19 years. Lake Iseo, together with the four other deep subalpine lakes (Maggiore, Lugano, Como, Garda), holds about $80 \%$ of the country's total freshwater. It is an important water resource for the densely populated and highly industrialized region of Lombardy. Besides its importance for the industry, agriculture, and animal breeding, Lake Iseo is also of particular naturalistic and recreational attraction. Environmental degradation phenomena are the eutrophication caused by the inflow of excessive nutrients from the 
catchment area [24], the blooms of potentially toxic cyanobacteria [25], climate change [26], and contamination by organic pollutants and microplastics [23].

For this study, three sampling sites at the northern end of the lake were selected, where the area is affected by the wastewater discharged from the WWTP located near the mouth of the Oglio River, the lake's main tributary (Figure 1): Site 1 (Lovere; $45^{\circ} 48^{\prime} 31.8^{\prime \prime} \mathrm{N}$ $10^{\circ} 04^{\prime} 10.9^{\prime \prime} \mathrm{E}$ ) on the left shore; site 2 (Costa Volpino; $45^{\circ} 48^{\prime} 33.4^{\prime \prime} \mathrm{N} 10^{\circ} 05^{\prime} 51.2^{\prime \prime} \mathrm{E}$ ) near the mouth of the Oglio River; site 3 (Castro; $45^{\circ} 48^{\prime} 07.3^{\prime \prime} \mathrm{N} 10^{\circ} 04^{\prime} 00.0^{\prime \prime} \mathrm{E}$ ) on the left shore, further away from the WWTP (Figure 1). These sites were selected since numerous mussels are attached to shady surfaces (stones and steel boat ropes) in the marinas and/or along the quaysides.

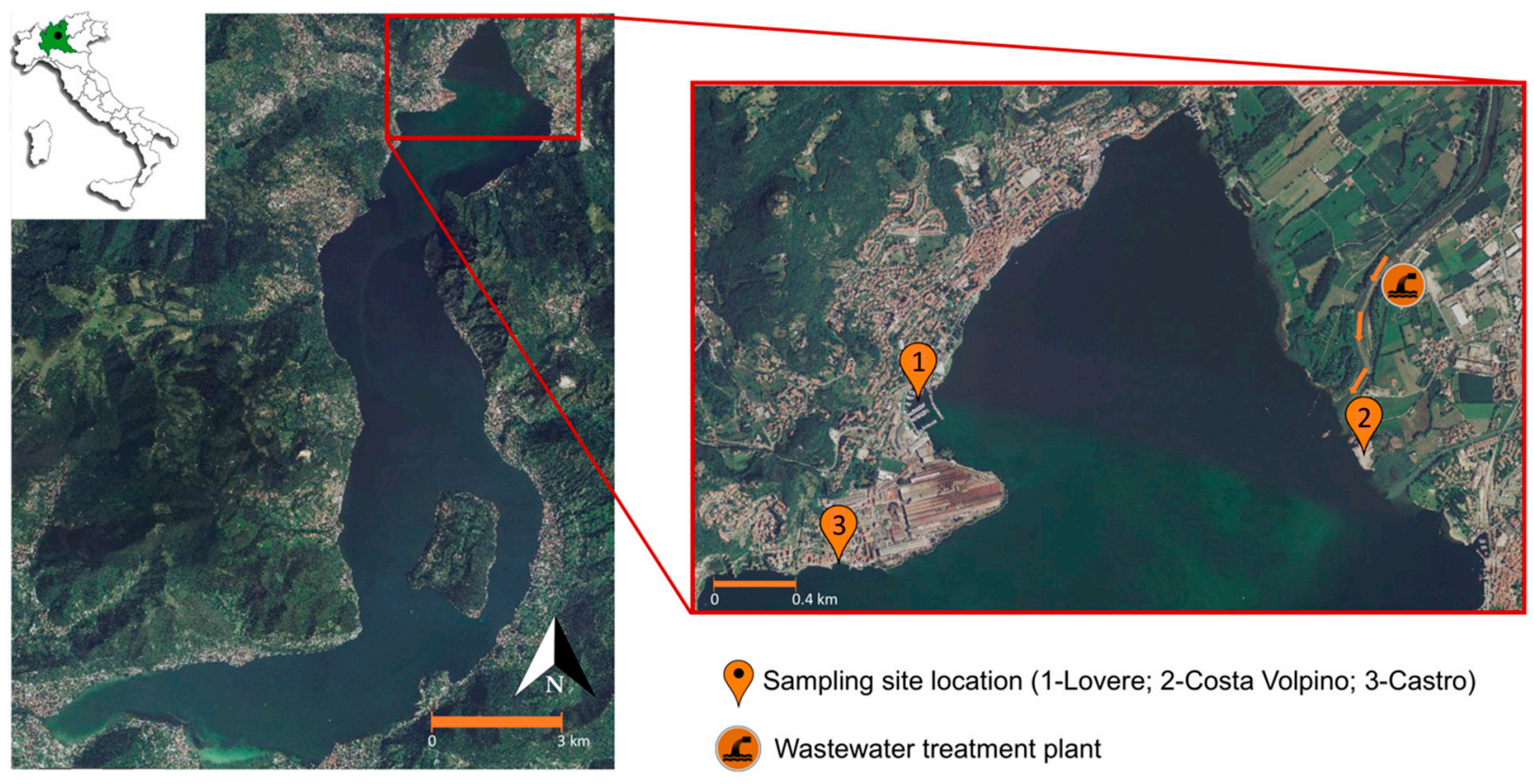

Figure 1. Study area: Lake Iseo (north Italy) on the left and detail of the northern end of the lake (on the right). Location of the three sampling sites (1: Lovere; 2: Costa Volpino; 3: Castro) and of the wastewater treatment plant on the Oglio River (orange arrow: Flow direction).

\subsection{Determination of Physicochemical Parameters of Water}

Physicochemical water parameters at each site were measured on 15 July 2020, since they can affect the filtration efficiency of zebra mussels [27]. Temperature $\left({ }^{\circ} \mathrm{C}\right)$, oxygen concentration $\left(\mathrm{mg} \mathrm{L}^{-1}\right), \mathrm{pH}$, and conductivity $\left(\mathrm{mS} \mathrm{cm}^{-1}\right)$ were measured using probes HI 9147 (oxygen), HI 9125 (pH and temperature), and HI 9033 (conductivity) (Hanna Instruments Inc., Woonsocket, RI, USA). Three replicates were taken for each parameter.

\subsection{Sampling and Biometric Analysis of Dreissena polymorpha}

Zebra mussels ( $\mathrm{n}=60$ per site) were also sampled on 15 July 2020 by hand at $1-2 \mathrm{~m}$ depth on stones and boat ropes at the three sites. Only living individuals with no visible signs of damage were collected. For each mussel, shell length (L), width (W), and height $(\mathrm{H})$ were measured to the nearest $0.01 \mathrm{~mm}$ using digital calipers while avoiding contamination. The samples were placed in precleaned glass beakers, covered with aluminum foil, and transported refrigerated $\left(+4{ }^{\circ} \mathrm{C}\right)$ to the laboratory within a few hours after collection and immediately frozen $\left(-20^{\circ} \mathrm{C}\right)$ whole (in their shell) until microplastic analysis [28]. 


\subsection{Microplastic Analysis}

Frozen D. polimorpha specimens were sent in dry ice to Bioscience Research Center (BsRC, Orbetello, Italy) to determine microplastic content. Samples ( $\mathrm{n}=60$ per site) were pooled and analyzed in replicates $(\mathrm{n}=3,20$ animals per pool).

A total amount of about $5 \mathrm{~g}$ per sample replicate $(\mathrm{n}=20)$ was added of a digestion solution of $\mathrm{H}_{2} \mathrm{O}_{2}: \mathrm{H}_{2} \mathrm{O}\left(1: 2 v / v\right.$; final $\mathrm{H}_{2} \mathrm{O}_{2}$ of $\left.15 \%\right)$ in opportunely sized glass Becker to allow the optimal digestion process. Criteria used in this study to the selection of the better digestion method targeted the general criteria reported by recent literature [29]. The quantity of digestion solution added was in a ratio $1: 1 \mathrm{w} / \mathrm{v}$ in respect to the sample wet weight. Glass Becker were digested in an ultrasonic bath for $50 \mathrm{~min}$ at $35^{\circ} \mathrm{C}(40 \mathrm{KHtz}$; ArgoLab, DU series) and observed to evaluate the occurrence of complete tissue digestion at the end of the process and otherwise, the digestion was repeated until complete dissolution of tissue at the end of this step. To ensure that the ultrasound extraction did not damage or fragment the microplastics before analyses, we performed positive controls $(n=5)$ adding to the extraction solution a known number of recognizable microplastic fragments and filaments previously measured by microscopy. Any of the added microparticles resulted significantly fragmented $(p>0.05 ; t$-test comparing sizes of added marked microplastics with the size of recovered ones) by the sonication stage under experimental condition applied in this study. In the case of presence of residual coriaceous structures (i.e., shells and/or shell fragments), these undigested solid fragments were collected by micro-tweezers and explored by stereomicroscopy to exclude the residual presence of microplastics. Extracts were collected by vacuum filtration on Anodisc ${ }^{\mathrm{TM}}$ (GE Healthcare Ltd., Buckinghamshire, UK) to perform chemical analyses. The Anodisc ${ }^{\mathrm{TM}}$ used in this study was $47 \mathrm{~mm}$ of diameter and $0.2 \mu \mathrm{m}$ of pore size; if organic digested colloids saturated filter pores, more Anodisc ${ }^{\mathrm{TM}}$ filters were used for the same extract and lectures of each of them were added. Microplastic of interest in this study were included in the range of size of $10-5000 \mu \mathrm{m}$; the minimum size of $10 \mu \mathrm{m}$ was chosen as limit of quantification (LOQ) based on the limit of detection of $\mu$ FT-IR used for chemical determinations on targeted particles. Anodisc ${ }^{\mathrm{TM}}$ size of pore was considered satisfactory to retain microplastic particles of specific interest (range 10-5000 $\mu \mathrm{m}$ ).

Collected samples were analyzed by microscopy associated with Fourier transform infrared spectroscopy ( $\mu$ FT-IR Nicolet iN 10MX, Thermo Fischer Scientific ${ }^{\circledR}$ Waltham, MA, USA Thermo Scientific) using a liquid nitrogen cooled MCT-A detector that operates in the spectral range of $7800-1200 \mathrm{~cm}^{-1}$ by the transmission technique. Spectral matches acquired on unknown particles were compared with the reference library (OMNIC ${ }^{\mathrm{TM}}$ Picta $^{\mathrm{TM}}$, Thermo Fisher Scientific Inc., Milan, Italy) software libraries integrated with libraries collected by BsRC on reference materials); only spectral matches $>90 \%$ were considered; Limit of Detection of the chemical analysis is $10 \mu \mathrm{m}$ of particle size. High value of threshold back recognition of spectral matches was imposed to reduce the risk of false positive. For each particle, spectra were collected at 10 different points to calculate the mean chemical spectrum associated to the analyzed particle. Matches with libraries were performed on the mean spectrum collected. The chemical identification of the microparticle was done, firstly, by the expert operator who evaluated whether the average spectrum obtained from the analysis of the unknown microparticle could be attributed without any doubts, to the recognition performed by the software. Particles $<90 \%$ before being considered as negative were evaluated case by case by the operator who established, on the basis of the spectral trend detected, whether the recorded match might be due to a false negative rather than an actual negative. If a false negative was suspected, the operator took the microparticle and performed a bland cleaning of the surface of the microparticle with ethyl alcohol or $\mathrm{H}_{2} \mathrm{O}_{2}$ and a new spectral acquisition. Alternatively, the operator considered using a different support base for spectral acquisition operating in transmission mode (i.e., $\mathrm{BaF}_{2}$ instead of Anodisc $\left.{ }^{\mathrm{TM}}\right)$. At the end of the exposed acquisition process, false negatives were excluded, and all positive matches resulted $>90 \%$. Particles $<0.5-10 \mu \mathrm{m}$ particles were not identified. An example of $\mu$ FT-IR analyses performed on tested samples is reported in Figure 2. 


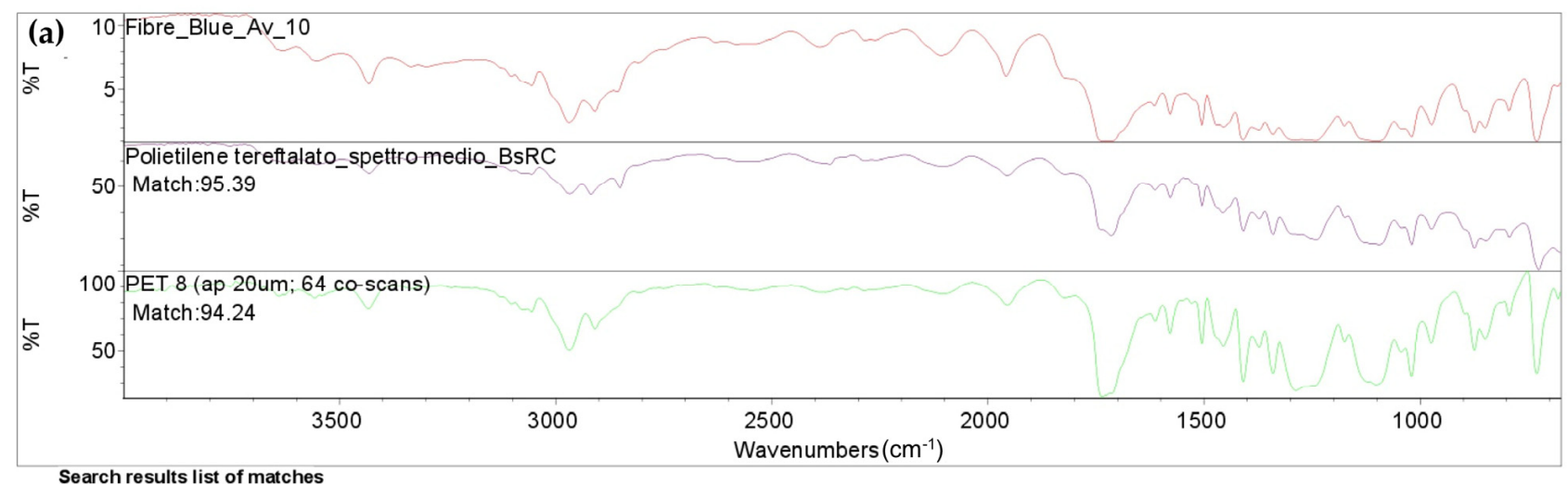

Search results list of matches

\begin{tabular}{cccll} 
& Index & Match & Compound Name & Library Name \\
1 & 5 & 95.39 & Polietilene tereftalato_spettro medio_BsRC & Plastics_BsRC \\
2 & 125 & 94.24 & PET 8 (ap 20um; 64 co-scans) & Microplastics Reflection \\
3 & 138 & 93.59 & PET 10 (ap 50um; 64 co-scans) & Microplastics Reflection \\
4 & 137 & 93.09 & PET 9 (ap 50um;64 co-scans) & Microplastics Reflection \\
5 & 127 & 92.76 & PET 10 (ap 20um; 64 co-scans) & Microplastics Reflection Reflection \\
6 & 123 & 92.22 & PET 6 (ap 20um; 64 co-scans) & Microplastics Reflection \\
7 & 119 & 91.71 & PET 2 (ap 20um;64 co-scans) & Microplastics Reflection \\
8 & 126 & 91.57 & PET 9 (ap 20um; 64 co-scans) & Microplastics Reflection \\
9 & 136 & 91.50 & PET 8 (ap 50um;64 co-scans) & Microplastics Reflection \\
\hline 10 & 128 & 89.63 & PET (ap 20um; 64 co-scans) 10 spectra Average & \\
\hline
\end{tabular}

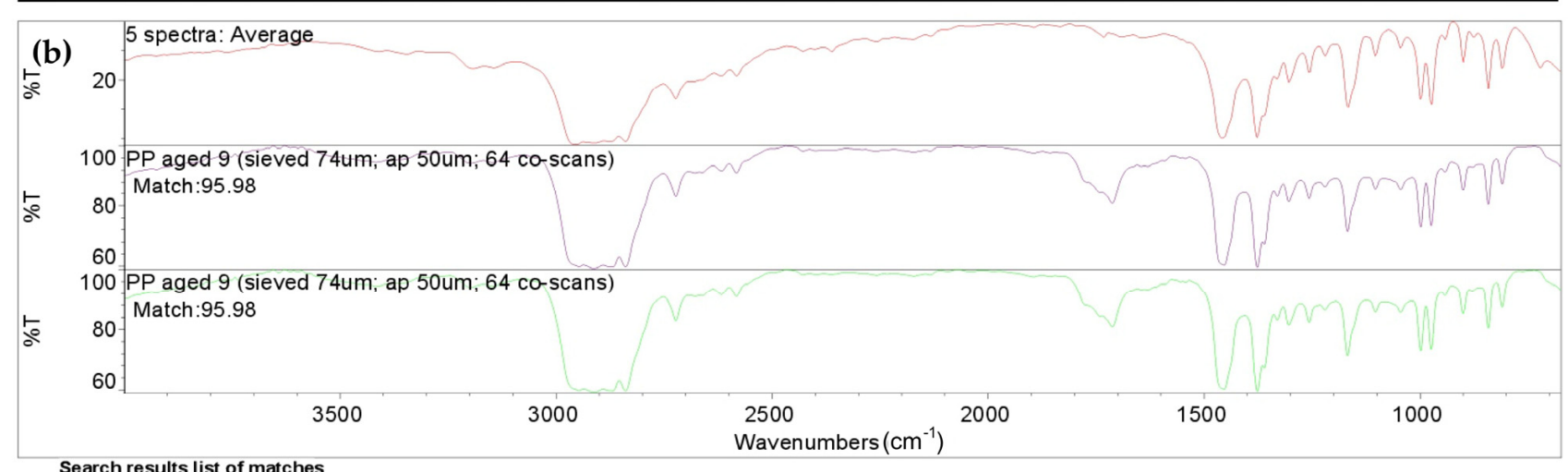

Search results list of matches

$\begin{array}{cccl} & \text { Index } & \text { Match } & \text { Compound Name } \\ 1 & 159 & 95.98 & \text { PP aged 9 (sieved 74um; ap 50um; 64 co-scans) } \\ 2 & 148 & 95.98 & \text { PP aged 9 (sieved 74um; ap 50um; 64 co-scans) } \\ 3 & 182 & 95.71 & \text { PP 10 (sieved 150um; ap 50um; 64 co-scans) } \\ 4 & 176 & 95.45 & \text { PP 4 (sieved 150um; ap 50um; 64 co-scans) } \\ 5 & 194 & 95.31 & \text { PP sheet (20um ap; 64 co-scans) 10 spectra: Average } \\ 6 & 165 & 94.20 & \text { PP 4 (sieved 150um; ap 20um; 64 co-scans) } \\ 7 & 171 & 93.97 & \text { PP 10 (sieved 150um; ap 20um; 64 co-scans) } \\ 8 & 192 & 92.89 & \text { PP sheet 9 (20um ap; 64 co-scans) } \\ 9 & 152 & 92.66 & \text { PP aged 2 (sieved 74um; ap 50um; 64 co-scans) } \\ 10 & 141 & 92.66 & \text { PP aged 2 (sieved 74um; ap 50um; 64 co-scans) }\end{array}$

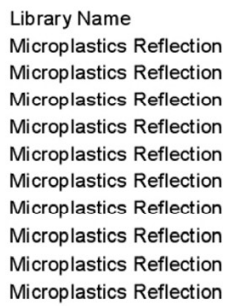

Figure 2. Average spectrum of a PET (polyethylene terephthalate) (a) and PP (polypropylene); (b) microparticle found in the samples analyzed (red lines) and the spectral match with the reference library (other colors).

\section{Quality Assurance/Quality Control (QA/QC)}

The general quality of the method adopted to determine microplastic used in this study was optimized and/or checked according to guidelines reported in the recent literature [29,30]. In particular, following quality criteria reported by literature concerning sample treatments and analyses, lab preparation, clean air conditions, negative/positive controls and polymer ID, the total accumulated score obtained by this study was 10/10 [30].

Samples treatments were performed under air-controlled conditions to avoid airborne microplastic pollution using a dedicated clean chamber equipped with HEPA-II filtration to minimize microplastic pollution. Thoroughly rinsed glassware was used at each stage of the process and both blanks and spiked samples were analyzed to evaluate the performance of the whole process. Blanks were performed by using extraction solutions as samples 
$(n=5)$, because of results obtained on blanks (mean $0.004 \pm 0.009$ items $/ L$, recovered items was a white filament of polyethylene terephthalate-PET), data reported in this study were not corrected by microplastics recorded in blanks because it was negligible. Spiked samples were extracted to evaluate recovery. Pooled mollusk tissues were added with 0.14 items $/ \mathrm{g}$ of marked microplastics (polypropylene-PP 23-60 $\mu \mathrm{m}$ blue and PET 35-100 $\mu \mathrm{m}$ white; $\mathrm{n}=5$ ) to evaluate recoveries ( $\mathrm{PP}=97.1 \pm 7.8 \%$; $\mathrm{PET}=94.3 \pm 6.4 \%$ ).

QA\&QC activities performed to ensure the general quality of the used method were optimized just to ensure high performance of recovery within the range of size of specific interest; particles below $0.2 \mu \mathrm{m}$, if present, were lost during the filtration step; nevertheless, $0.2 \mu \mathrm{m}$ particle size was more than two orders of magnitude lower than $\mu$ FT-IR LOQ and this loss was considered unsignificant for the specific purposes of this study.

\subsection{Statistical Analysis}

The Kolmogorov-Smirnov test was performed to determine whether our dataset was well-modeled by normal distribution. Since the null hypothesis for normal distribution could not be rejected, differences in physicochemical parameters, biometric features (L, $\mathrm{W}, \mathrm{H}$ ) and items/specimens were analyzed using the non-parametric Kruskal-Wallis test, whereases difference in microplastic size among Costa Volpino and Lovere was analyzed through Mann-Whitney U test, considering that only 2 items were found in Castro. Dunn's post-hoc test was used for multiple comparisons. Differences in microplastic shape, type, and color between the three sampling sites were tested using the chi-square test. Statistical significance was set at $p$-value $<0.05$. All analyses were performed using RStudio version 3.4.3.

\section{Results and Discussion}

The freshwater zebra mussel (D. polymorpha) has been widely used in laboratory studies as a model to evaluate the exposure and the effects of microplastics on freshwater organisms [15,31,32]. However, field studies have never been performed to date. This is the first study to analyze the size, shape, color, and chemical composition of microplastics in the invasive freshwater species D. polymorpha from Lake Iseo.

The physicochemical water parameters were within the seasonal range and in line with the data of the Regional Agency for Environmental Protection [33]: Temperature ranged from 18.9 (Costa Volpino) to $19.4^{\circ} \mathrm{C}$ (Lovere), $\mathrm{pH}$ from 8.57 (Castro) to 8.74 (Costa Volpino), conductivity from 215 (Castro) to $238 \mathrm{mS} \mathrm{cm}^{-1}$ (Costa Volpino); dissolved oxygen ranged from 8.21 to $8.32 \mathrm{mg} \mathrm{L}^{-1}$ (Table 1 ). There were no statistically significant differences in these parameters between the three sampling sites (Kruskal-Wallis test; $p>0.05$ ).

Table 1. Physicochemical parameters of water (mean $\pm[S D]$ standard deviation) at the three sampling sites.

\begin{tabular}{ccccc}
\hline Site & $\begin{array}{c}\text { Temperature } \\
\left({ }^{\circ} \mathbf{C}\right)\end{array}$ & $\mathbf{p H}$ & $\begin{array}{c}\text { Conductivity } \\
\left(\mu \mathbf{S ~ c m}^{-\mathbf{1}}\right)\end{array}$ & $\begin{array}{c}\text { Dissolved } \\
\text { Oxygen } \\
\left(\mathbf{m g ~ L}^{-1}\right)\end{array}$ \\
\hline $\begin{array}{c}\text { Lovere } \\
\text { Costa Volpino }\end{array}$ & $19.4 \pm 0.12$ & $8.63 \pm 0.10$ & $226 \pm 2.65$ & $8.32 \pm 0.23$ \\
Castro & $18.9 \pm 0.13$ & $8.74 \pm 0.08$ & $238 \pm 1.78$ & $8.21 \pm 0.35$ \\
\hline
\end{tabular}

Biometric features of D. polymorpha at each site are presented in Table 2. 
Table 2. Mean $( \pm \mathrm{SD})$ biometric features (length, width, height) of D. polymorpha from the three sampling sites.

\begin{tabular}{cccc}
\hline Site & Length $(\mathbf{m m})$ & Width $(\mathbf{m m})$ & Height $(\mathbf{m m})$ \\
\hline Lovere & $13.64 \pm 1.83$ & $7.41 \pm 0.93$ & $6.62 \pm 0.88$ \\
Costa Volpino & $13.89 \pm 2.03$ & $7.48 \pm 1.23$ & $6.61 \pm 0.65$ \\
Castro & $13.76 \pm 1.62$ & $7.42 \pm 0.71$ & $6.47 \pm 0.57$ \\
\hline
\end{tabular}

Average shell length ranged from $13.64 \mathrm{~mm}$ (Lovere) to $13.89 \mathrm{~mm}$ (Costa Volpino) but did not differ significantly among the three sampling sites (Kruskal-Wallis test; $p>0.05$ ). Average shell width ranged from $7.41 \mathrm{~mm}$ (Lovere) to $7.48 \mathrm{~mm}$ (Costa Volpino) and average height ranged from $6.47 \mathrm{~mm}$ (Castro) to $6.62 \mathrm{~mm}$ (Lovere), neither of which significantly differed among the three sites (Kruskal-Wallis test; $p>0.05$ ).

The filtration rate of $D$. polymorpha depends largely on water temperature [27]. The filtration activity of zebra mussels is optimal and does not vary at temperatures between 5 and $20^{\circ} \mathrm{C}$ [27]. The filtration rate is lower in large D. polymorpha individuals $(>22 \mathrm{~mm}$ length) than in smaller mussels because of age-related degeneration [27]. Since the water temperature and the average shell length of individuals at the three sites were within the optimal range, it can be assumed that their filtration rate was optimal.

Table 3 presents the mean number of microplastics items per specimen (item/specimen) grouped by particle shape, color, size, and chemical composition. The mean size of items did not differ between Costa Volpino and Lovere (Mann-Whitney U test; $p>0.05$ ). In this study, we found that zebra mussels retained particles $>149 \mu \mathrm{m}$, though they can also filter much larger particles $(2289.17 \mu \mathrm{m})$. Horgan and Mills [20] observed that zebra mussels 9 to $21 \mathrm{~mm}$ in length size could clear spherical particles 900 to $1200 \mu \mathrm{m}$ in diameter.

Table 3. Microplastics measured in Dreissena polymorpha at the three sampling sites reported as total items, items/animal, and standard deviation $( \pm \mathrm{SD})$, shape, color, chemical composition, and range (min-max). PET denotes polyethylene terephthalate; PP, polypropylene; PA, resin polyamide resin; PVC, polyvinyl chloride.

\begin{tabular}{|c|c|c|c|c|c|c|c|c|c|c|}
\hline Site & $\begin{array}{l}\text { Total } \\
\text { Items }\end{array}$ & Items/Animal & SD & Shape & Color & $\begin{array}{l}\text { Chemical } \\
\text { Composition }\end{array}$ & $\begin{array}{l}\text { Mean } \\
\text { Size } \\
(\mu \mathrm{m})\end{array}$ & SD & $\begin{array}{l}\text { Min } \\
(\mu \mathrm{m})\end{array}$ & $\begin{array}{l}\operatorname{Max} \\
(\mu \mathrm{m})\end{array}$ \\
\hline Lovere & 4 & 0.07 & 0.25 & $\begin{array}{l}\text { fragment } \\
\text { fragment } \\
\text { fragment } \\
\text { fragment }\end{array}$ & $\begin{array}{l}\text { blue } \\
\text { blue } \\
\text { white } \\
\text { white }\end{array}$ & $\begin{array}{c}\text { PET } \\
\text { PET } \\
\text { PA resin } \\
\text { PA resin }\end{array}$ & 182.44 & 46.43 & 149.61 & 215.27 \\
\hline $\begin{array}{l}\text { Costa } \\
\text { Volpino }\end{array}$ & 14 & 0.23 & 0.43 & $\begin{array}{l}\text { fiber } \\
\text { fiber } \\
\text { fiber } \\
\text { fiber } \\
\text { fiber } \\
\text { fiber } \\
\text { fiber } \\
\text { fiber } \\
\text { fiber } \\
\text { fiber } \\
\text { fragment } \\
\text { fragment } \\
\text { fragment } \\
\text { fragment }\end{array}$ & $\begin{array}{l}\text { blue } \\
\text { blue } \\
\text { blue } \\
\text { blue } \\
\text { blue } \\
\text { blue } \\
\text { red } \\
\text { red } \\
\text { red } \\
\text { red } \\
\text { blue } \\
\text { blue } \\
\text { blue } \\
\text { blue }\end{array}$ & $\begin{array}{c}\text { PET } \\
\text { PET } \\
\text { PET } \\
\text { PET } \\
\text { PET } \\
\text { PET } \\
\text { Nylon } \\
\text { Nylon } \\
\text { Nylon } \\
\text { Nylon } \\
\text { PP } \\
\text { PP } \\
\text { PP } \\
\text { PP }\end{array}$ & 867.0 & 1231.6 & 149.1 & 2289.17 \\
\hline Castro & 2 & 0.03 & 0.18 & $\begin{array}{l}\text { fiber } \\
\text { fiber }\end{array}$ & $\begin{array}{c}\text { green } \\
\text { red }\end{array}$ & $\begin{array}{l}\text { PET } \\
\text { PVC }\end{array}$ & 1735.73 & 101.85 & 1163.71 & 1807.75 \\
\hline
\end{tabular}

The items/specimen frequency was (mean $\pm \mathrm{SD}$ ): Costa Volpino $(0.23 \pm 0.71)>$ Lovere $(0.13 \pm 1.41)>$ Castro $(0.03 \pm 0.58)$ (Table 2$)$. There was a statistically significant 
difference in the items/specimen frequency between the sampling sites (Kruskal-Wallis test; $p=0.001$ ), with a significantly higher concentration in the samples from Costa Volpino compared to those from Lovere (Dunn's test; $p=0.011$ ) and Castro (Dunn's test; $p=0.001$ ). No significant difference in items/specimens were found between Lovere and Castro (Dunn's test; $p>0.05$ ). These findings are shared by Sighicelli et al. [23] who surveyed the occurrence of microplastics in the surface water of subalpine lakes, including Lake Iseo, and found the highest number of items $\left(57,000 \pm 36,000\right.$ particles $\left./ \mathrm{km}^{2}\right)$ in the north end of Lake Iseo, where the area is affected by sewage effluents from the Oglio River. The data support our hypothesis that zebra mussels accumulate higher amounts of microplastics near the wastewaters from the Oglio River and that the effluent from the WWTP contains microplastics that are subsequently released into the environment.

The retention efficiency of a particle size in zebra mussel was estimated by Lei et al. [19] by dividing the filtration rate of a given size class by the maximum filtration rate for all size classes: Retention efficiency was $6 \%$ and $29 \%$ for microspheres 0.5 and $1.0 \mu \mathrm{m}$ in diameter, respectively, and was uniformly high (87-100\%) for all larger microspheres. This may explain why only large items were recorded in the zebra mussels sampled from Lake Iseo.

Fibers $(n=12)$ were found in samples from the Costa Volpino $(n=10)$ and the Castro $(\mathrm{n}=2)$ site, whereas fragments $(\mathrm{n}=8)$ were found in samples from the Costa Volpino $(\mathrm{n}=4)$ and the Lovere $(\mathrm{n}=4)$ site (Table 2). There were significant differences in the shape frequencies between the three sites $\left(\chi^{2}=8.095\right.$; chi-square test, $\left.p=0.017\right)$. As reported by previous studies of microplastics pollutions in freshwater environments [34-37], we noted that fibers were the most abundant microplastic found in the samples from all three sites, whereas fragments were more commonly found in the samples from the sites (Costa Volpino and Lovere) with greater anthropogenic impact due to their proximity to wastewater inflow, as reported elsewhere [37].

The predominant color of the microplastics in our samples were blue $(60 \%)$, red $(25 \%)$, white $(10 \%)$, and green $(5 \%)$. The chi-square test showed significant differences in the color frequencies between the three sites $\left(\chi^{2}=20.14 ; p=0.002\right)$. The source of the blue particles is unclear, but their prevalence has been reported in previous studies $[37,38]$.

The chemical composition of microplastics, in descending order, was: $45 \%$ polyethylene terephthalate (PET); $20 \%$ nylon; $20 \%$ polypropylene (PP), $10 \%$ polyamide resin, and $5 \%$ polyvinyl chloride (PVC) (Figure 3a). However, the chemical composition varied between the sites (Figure 3b): PET was present in all three sites (Lovere: 50\%; Costa Volpino: $43 \%$; Castro: 50\%), while the other compounds (nylon, PA resin, PP, PVC) were found only in certain sites (Figure $3 b$ ). The chi-square test showed significant differences in chemical composition frequency between the three sites $\left(\chi^{2}=20.48 ; p=0.008\right)$. The chemical composition was in line with the findings reported by Sighicelli et al. [23] in which PET and PP were highest in frequency ( $45 \%$ and $15 \%$, respectively) in water samples collected from the three main Italian subalpine lakes (Maggiore, Iseo and Garda).

Field studies of microplastics accumulation in zebra mussels are lacking. A study in quagga mussels (Dreissena bugensis) from Lake Mead and Lake Mohave in the Lake Mead National Recreation Area (USA) found higher items/specimens (range, 2.7-13.0) [37]. As regards other freshwater bivalve species, Su et al. [38] conducted a survey of microplastic pollution in Asian clams (Corbicula fluminea) from 21 sites in the Middle-Lower Yangtze River Basin and found microplastics at a concentration of 0.4-5.0 items/individual. Recently, Baldwin et al. [37] found a considerably higher microplastics concentration compared to our results (average 51.7 items / organism, range 18-105) in the benthic filter-feeder C. fluminea collected from the Lake Mead National Recreation Area (USA) probably due to its close contact with sediment. 
a)
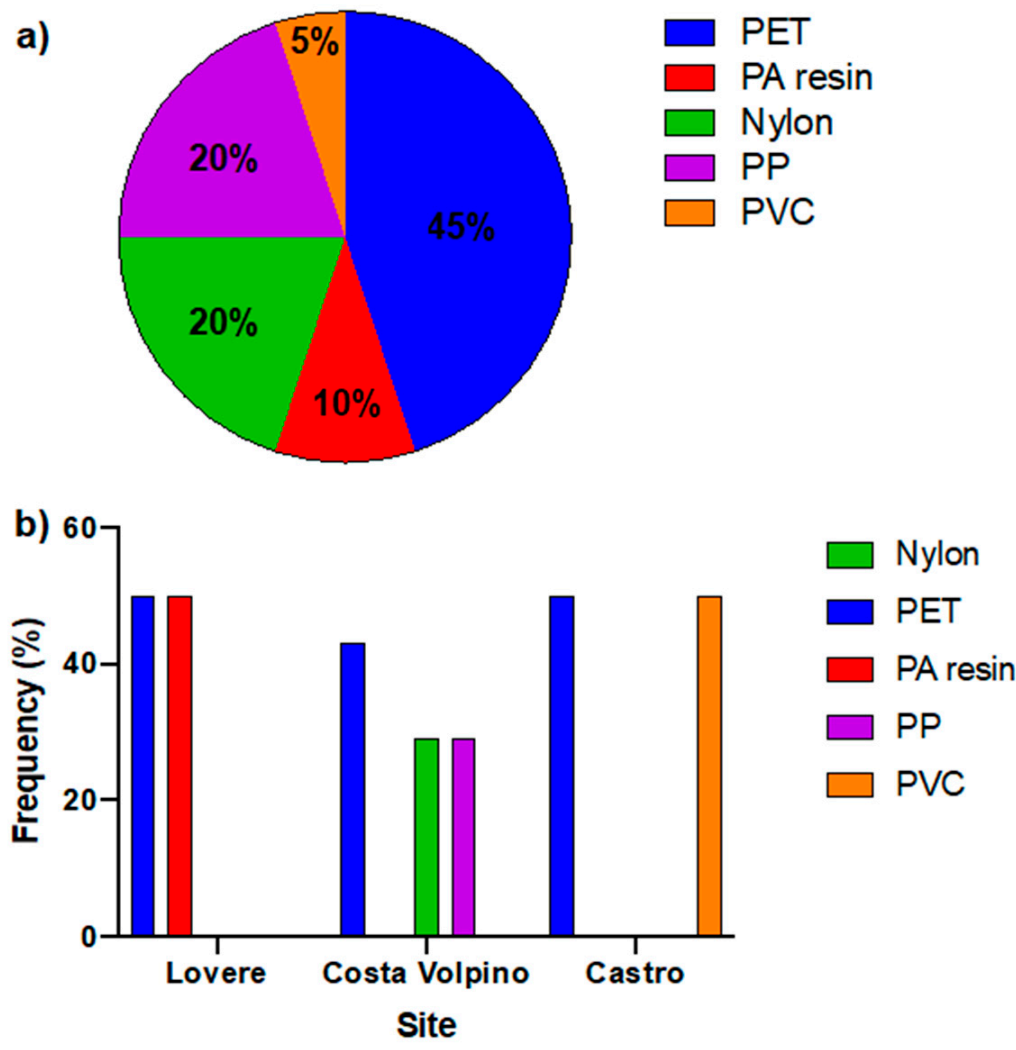

Figure 3. (a) Chemical composition ( $\%$ frequency) of total microplastics $(n=20)$ in samples from Lake Iseo; (b) Frequency (in percentage) of each chemical compound (nylon, polyethylene terephthalatePET, polyamide resin, polypropylene-PP, polyvinyl chloride-PVC) in the samples from the three sites.

\section{Conclusions}

Dreissena polymorpha may be considered a potential bioindicator to measure pollution in aquatic ecosystems. It is able to filter large volumes of water and it has been estimated that $D$. polymorpha filters about $1 / 800$ of the epilimnion water volume daily in Lake Iseo [22]. Our findings showed that zebra mussels may provide a valid tool to monitor microplastics pollution in lakes and that our hypothesis that the zebra mussels from the sampling sites nearer the WWTP accumulate higher amounts of microplastics was correct. It is important to point out that this invasive species poses a serious threat to aquatic biodiversity conservation; its use as a bioindicator to monitor aquatic ecosystems may be a sustainable way to manage aquatic ecosystems, reducing the use of native species, most of which are endangered.

Author Contributions: Conceptualization, P.P.; data curation, P.P., M.B., and M.R.; investigation, P.P., M.P., S.A., V.M., M.B., A.D., E.P., and M.R.; methodology, P.P., M.P., S.A., V.M., M.B., A.D., E.P., and M.R.; supervision, M.R.; writing—original draft, P.P. and M.R.; writing—review and editing, M.P., V.M., E.P., and M.R. All authors have read and agreed to the published version of the manuscript.

Funding: This research received no external funding.

Institutional Review Board Statement: Not applicable.

Informed Consent Statement: Not applicable.

Data Availability Statement: Not applicable.

Conflicts of Interest: The authors declare no conflict of interest. 


\section{References}

1. Akdogan, Z.; Guven, B. Microplastics in the environment: A critical review of current understanding and identification of future research needs. Environ. Pollut. 2019, 254, 113011. [CrossRef] [PubMed]

2. Van Wezel, A.; Caris, I.; Kools, S.A. Release of primary microplastics from consumer products to wastewater in The Netherlands. Environ. Toxicol. Chem. 2016, 35, 1627-1631. [CrossRef] [PubMed]

3. Lehtiniemi, M.; Hartikainen, S.; Näkki, P.; Engström-Öst, J.; Koistinen, A.; Setälä, O. Size matters more than shape: Ingestion of primary and secondary microplastics by small predators. Food Webs 2018, 17, e00097. [CrossRef]

4. Moore, C.J. Synthetic polymers in the marine environment: A rapidly increasing, long-term threat. Environ. Res. 2008, 108, 131-139. [CrossRef]

5. Wright, S.L.; Thompson, R.C.; Galloway, T.S. The physical impacts of microplastics on marine organisms: A review. Environ. Pollut. 2013, 178, 483-492. [CrossRef] [PubMed]

6. De Ruijter, V.N.; Redondo-Hasselerharm, P.E.; Gouin, T.; Koelmans, A.A. Quality criteria for microplastic effect studies in the context of risk assessment: A critical review. Environ. Sci. Technol. 2020, 54, 11692-11705. [CrossRef]

7. Eerkes-Medrano, D.; Thompson, R.C.; Aldridge, D.C. Microplastics in freshwater systems: A review of the emerging threats, identification of knowledge gaps and prioritisation of research needs. Water Res. 2015, 75, 63-82. [CrossRef]

8. Al-Jaibachi, R.; Cuthbert, R.N.; Callaghan, A. Up and away: Ontogenic transference as a pathway for aerial dispersal of microplastics. Biol. Lett. 2018, 14, 20180479. [CrossRef]

9. Bakir, A.; Rowland, S.J.; Thompson, R.C. Transport of persistent organic pollutants by microplastics in estuarine conditions. Estuar. Coast. Shelf Sci. 2014, 140, 14-21. [CrossRef]

10. Gerhardt, A. Bioindicator Species and Their Use in Biomonitoring. Environmental Monitoring I. Encyclopedia of Life Support Systems (EOLSS). Developed under the Auspices of the UNESCO; Eolss Publishers: Oxford, UK, 2002.

11. Roveta, C.; Annibaldi, A.; Afghan, A.; Calcinai, B.; Di Camillo, C.G.; Gregorin, C.; Illuminati, S.; Pulido Mantas, T.; Truzzi, C.; Puce, S. Biomonitoring of Heavy Metals: The Unexplored Role of Marine Sessile Taxa. Appl. Sci. 2021, 11, 580. [CrossRef]

12. Boening, D.W. An evaluation of bivalves as biomonitors of heavy metals pollution in marine waters. Environ. Monit. Assess. 1999, 55, 459-470. [CrossRef]

13. Waykar, B.; Deshmukh, G. Evaluation of bivalves as bioindicators of metal pollution in freshwater. Bull. Environ. Contam. Toxicol. 2012, 88, 48-53. [CrossRef]

14. Hamza-Chaffai, A. Usefulness of bioindicators and biomarkers in pollution biomonitoring. Int. J. Biotechnol. Wellness Ind. 2014, 3, 19-26. [CrossRef]

15. Binelli, A.; Pietrelli, L.; Di Vito, S.; Coscia, L.; Sighicelli, M.; Della Torre, C.; Parenti, C.C.; Magni, S. Hazard evaluation of plastic mixtures from four Italian subalpine great lakes on the basis of laboratory exposures of zebra mussels. Sci. Total Environ. 2020, 699, 134366. [CrossRef] [PubMed]

16. Mackie, G.L.; Schloesser, D.W. Comparative biology of zebra mussels in Europe and North America: An overview. Am. Zool. 1996, 36, 244-258. [CrossRef]

17. Bosso, L.; De Conno, C.; Russo, D. Modelling the risk posed by the zebra mussel Dreissena polymorpha: Italy as a case study. Environ. Manage. 2017, 60, 304-313. [CrossRef] [PubMed]

18. Minier, C.; Abarnou, A.; Jaouen-Madoulet, A.; Le Guellec, A.M.; Tutundjian, R.; Bocquené, G.; Leboulenger, F. A pollutionmonitoring pilot study involving contaminant and biomarker measurements in the Seine Estuary, France, using zebra mussels (Dreissena polymorpha). Environ. Toxicol. Chem. 2006, 25, 112-119. [CrossRef]

19. Lei, J.; Payne, B.S.; Wang, S.Y. Filtration dynamics of the zebra mussel, Dreissena polymorpha. Can. J. Fish. Aquat. Sci. 1996, 53, 29-37. [CrossRef]

20. Horgan, M.J.; Mills, E.L. Clearance rates and filtering activity of zebra mussel (Dreissena polymorpha): Implications for freshwater lakes. Can. J. Fish. Aquat. Sci. 1997, 54, 249-255. [CrossRef]

21. Cappelletti, C.; Ciutti, F. Bivalvi alloctoni nel Lago di Garda. Biol. Ambient. 2017, 31, 169-173.

22. Roncaglio, P.; Borsani, G. Analisi della struttura di popolazione del mollusco bivalve Dreissena polymorpha (Pallas, 1771) nel Sebino (Lombardia, Italia settentrionale). Nat. Brescia. 2005, 34, 49-53.

23. Sighicelli, M.; Pietrelli, L.; Lecce, F.; Iannilli, V.; Falconieri, M.; Coscia, L.; Di Vito, S.; Nuglio, S.; Zampetti, G. Microplastic pollution in the surface waters of Italian Subalpine Lakes. Environ. Pollut. 2018, 236, 645-651. [CrossRef] [PubMed]

24. Salmaso, N.; Mosello, R.; Garibaldi, L.; Decet, F.; Brizzio, M.C.; Cordella, P. Vertical mixing as a determinant of trophic status in deep lakes: A case study from two lakes south of the Alps (Lake Garda and Lake Iseo). J. Limnol. 2003, 62, 33-41. [CrossRef]

25. Garibaldi, L.; Anzani, A.; Marieni, A.; Leoni, B.; Mosello, R. Studies on the phytoplankton of the deep subalpine Lake Iseo. J. Limnol. 2003, 62, 177-189. [CrossRef]

26. Mosello, R.; Ambrosetti, W.; Arisci, S.; Bettinetti, R.; Buzzi, F.; Calderoni, A.; Carrara, E.; De Bernardi, R.; Galassi, S.; Garibaldi, L.; et al. Evoluzione recente della qualità delle acque dei laghi profondi subalpini (Maggiore, Lugano, Como, Iseo e Garda) in risposta alle pressioni antropiche e alle variazioni climatiche. Biol. Ambient. 2010, 24, 167-177.

27. Reeders, H.H.; De Vaate, A.B. Zebra mussels (Dreissena polymorpha): A new perspective for water quality management. Hydrobiologia 1990, 200, 437. [CrossRef] 
28. Bråte, I.L.N.; Hurley, R.; Iversen, K.; Beyer, J.; Thomas, K.V.; Steindal, C.C.; Green, N.W.; Olsen, M.; Lusher, A. Mytilus spp. as sentinels for monitoring microplastic pollution in Norwegian coastal waters: A qualitative and quantitative study. Environ. Pollut. 2018, 243, 383-393. [CrossRef] [PubMed]

29. Enders, K.; Lenz, R.; do Sul, J.A.I.; Tagg, A.S.; Labrenz, M. When every particle matters: A QuEChERS approach to extract microplastics from environmental samples. MethodsX 2020, 7, 100784. [CrossRef] [PubMed]

30. Koelmans, A.A.; Nor, N.H.M.; Hermsen, E.; Kooi, M.; Mintenig, S.M.; De France, J. Microplastics in freshwaters and drinking water: Critical review and assessment of data quality. Water Res. 2019, 155, 410-422. [CrossRef]

31. Magni, S.; Parolini, M.; Della Torre, C.; Fernandes de Oliveira, L.; Catani, M.; Guzzinati, R.; Cavazzini, A.; Binelli, A. Multibiomarker investigation to assess toxicity induced by two antidepressants on Dreissena polymorpha. Sci. Total Environ. 2017, 578, 452-459. [CrossRef]

32. Magni, S.; Gagné, F.; André, C.; Della Torre, C.; Auclair, J.; Hanana, H.; Parenti, C.C.; Bonasoro, F.; Binelli, A. Evaluation of uptake and chronic toxicity of virgin polystyrene microbeads in freshwater zebra mussel Dreissena polymorpha (Mollusca: Bivalvia). Sci. Total Environ. 2018, 631, 778-788. [CrossRef] [PubMed]

33. ARPA Lombardia, 2020. Dati Analitici Corpi Idrici Lacustri. Available online: https://www.arpalombardia.it/Pages/Dati/ 2019/Acque/Dati-analitici-corpi-idrici-lacustri-2019.aspx?tipodati=0\&tema=Tema $\% 20$ ambientale\&sottotema=Acque $\% 20$ superficiali\&ordine $=1$ (accessed on 18 January 2021).

34. McCormick, A.; Hoellein, T.J.; Mason, S.A.; Schluep, J.; Kelly, J.J. Microplastic is an abundant and distinct microbial habitat in an urban river. Environ. Sci. Technol. 2014, 48, 11863-11871. [CrossRef]

35. Dris, R.; Gasperi, J.; Saad, M.; Mirande, C.; Tassin, B. Synthetic fibers in atmospheric fallout: A source of microplastics in the environment? Mar. Pollut. Bull. 2016, 104, 290-293. [CrossRef]

36. Baldwin, A.K.; Corsi, S.R.; Mason, S.A. Plastic debris in 29 Great Lakes tributaries: Relations to watershed attributes and hydrology. Environ. Sci. Technol. 2016, 50, 10377-10385. [CrossRef] [PubMed]

37. Baldwin, A.K.; Spanjer, A.R.; Rosen, M.R.; Thom, T. Microplastics in Lake Mead National Recreation Area, USA: Occurrence and biological uptake. PLoS ONE 2020, 15, e0228896. [CrossRef] [PubMed]

38. Su, L.; Cai, H.; Kolandhasamy, P.; Wu, C.; Rochman, C.M.; Shi, H. Using the Asian clam as an indicator of microplastic pollution in freshwater ecosystems. Environ. Pollut. 2018, 234, 347-355. [CrossRef] [PubMed] 